\title{
DIGITALCOMMONS
}

@WAYNESTATE-

Wayne State University

Law Faculty Research Publications

Law School

$1-1-2010$

\section{Reproductive Health as a Human Right}

Lance Gable

Wayne State University, lancegable@wayne.edu

\section{Recommended Citation}

Lance Gable, Reproductive Health as a Human Right, 60 Case W. Res. L. Rev. 957 (2010).

Available at: http://digitalcommons.wayne.edu/lawfrp/32

This Article is brought to you for free and open access by the Law School at DigitalCommons@WayneState. It has been accepted for inclusion in Law

Faculty Research Publications by an authorized administrator of DigitalCommons@WayneState. 


\title{
REPRODUCTIVE HEALTH AS A HUMAN RIGHT
}

\author{
Lance Gable ${ }^{\dagger}$
}

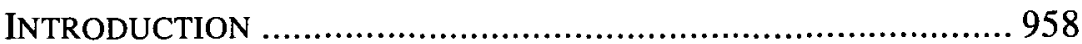

I. ThE Global State Of ReProductive HEAlTH............... 962

A. Maternal Mortality ............................................... 963

B. Access to Reproductive Health Services ....................... 964

C. Family Planning Services ........................................ 964

D. Abortion Services .................................................... 965

E. Prevalence of Female Genital Mutilation.................... 966

F. Sexually Transmitted Infections ............................... 967

G. Reproductive Health Indicators: Implications for Human

Rights .......................................................... 967

II. CONCEPTUALIZING REPRODUCTIVE HEALTH RIGHTS: THE REPRODUCTIVE RIGHTS MODEL AND THE RIGHT TO HEALTH

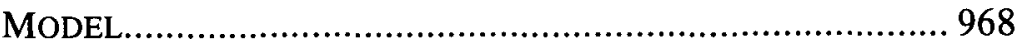

A. The Reproductive Rights Model ................................ 970

1. The Development of the Reproductive Rights Model Through the Women's Rights Movement .................. 971

2. The Development of the Reproductive Rights Model Through the Human Rights Movement ..................... 973

3. Reproductive Health Rights Under the Reproductive Rights Model ...................................................... 975

B. The Right to Health Model.................................... 976

1. Evolution of the Right to Health Through International

Treaty Law

$\uparrow$ Assistant Professor of Law, Wayne State University Law School. I would like to thank Tony Dillof, Benjamin Mason Meier, Cynthia Soohoo, Andrew Coan, and the attendees of the Case Western Reserve Law Review Symposium, Reproductive Rights, Human Rights, and the Human Right to Health, for helpful suggestions related to this Article. I also would like to thank Kaitlin McKenzie, Kunle Fadipe, Ahmad Chebab, and Lauren Andary for their invaluable assistance in researching this Article. 
2. Development of Right to Health Norms

3. Reproductive Health Rights Under the Right to Health Model. 982

III. Conceiving Reproductive Health as a Human

RIGHT 985

A. Bridging the Discourses: A Combined Model for Reproductive Health Rights 985

B. Expanding the Global Salience and Enforceability of Reproductive Health Rights ... 987

1. Recognition of Reproductive Health Rights in Law and Policy Decisions. 987

2. Developing the Normative Content of Reproductive Health Rights

3. Legal Recognition and Justiciability of Reproductive Health Rights 993

4. Developing Systemic Redundancy to Uphold Reproductive Health Rights.....

\section{INTRODUCTION}

The concepts of reproduction and health have an intimate and deeply rooted connection. Reproductive decisions and the process of reproduction have direct impacts on health, particularly the health of women. ${ }^{1}$ Reproductive health broadly encompasses health conditions and social conditions that affect reproductive functioning, whether a woman seeks to reproduce or to avoid reproduction. ${ }^{2}$ Successful reproduction requires a basic level of health in the sense that healthy reproductive and developmental functions are necessary in order to bring a pregnancy to term. Factors determining if and when a woman will decide to reproduce raise fundamental issues of autonomy,

1 Reproductive health and reproductive rights concerns apply to men as well, but much of the focus in this field is on the connection between women's health and women's rights in reproduction. See REBECCA J. COOK, BERNARD M. DicKens \& MAHMOUd F. Fathalla, REPRODUCTIVE HEALTH AND HUMAN RIGHTS: INTEGRATING MEDICINE, ETHICS, AND LAW 14-18 (2003) (explaining the importance of gender differences in the context of reproductive health).

2 Definitions of reproductive health have focused on both supporting reproductive functioning and self-regulation of fertility by women. See, e.g., Mahmoud F. Fathalla, Promotion of Research in Human Reproduction: Global Needs and Perspectives, 3 HUM. REPROD. 7, 7 (1988) (defining reproductive health as requiring, among other things, "that people have the ability to reproduce and the ability to regulate their fertility"); Mahmoud F. Fathalla, Reproductive Health: A Global Overview, 626 ANNALS N.Y. ACAD. SCI. 1, 1 (1991) ("Reproductive health . .. implies that people have the ability to reproduce, to regulate their fertility, and to practice and enjoy sexual relationships." (emphasis omitted)). 
privacy, and agency related to that woman's health choices, as well as that woman's ability to exercise those choices. ${ }^{3}$

The human rights paradigm provides an important perspective on the relationship between reproduction and health, as well as an essential tool for ensuring that reproductive health is achieved and reproductive rights are protected. ${ }^{4}$ Viewing this relationship through the lens of human rights reveals a close and multifaceted connection between reproductive health and human rights. Yet the recognition of reproductive health as a human right under international human rights law has been sporadic, piecemeal, and indirect. International human rights conventions do not explicitly establish a discrete human right to reproductive health, but they often recognize specific aspects of this right. ${ }^{5}$ Indeed, different components of a human right to reproductive health may be assembled through applying numerous human rights provisions to reproductive health. ${ }^{6}$ International reproductive health meetings and initiatives have bolstered this idea, increasingly invoking the human rights paradigm and embracing the linkage between upholding human rights and improved reproductive health.? Nevertheless, the recognition of reproductive health as a human right remains in flux, its development unfinished, its contours uncertain, and its widespread international acceptance tenuous.

This Article seeks to contribute to the conceptual understanding and practical interpretation of the human right to reproductive health, and in the process present a more cohesive definition of this right grounded in international human rights law. This Article argues that

3 See, e.g., Ruth Bader Ginsburg, Essay, Some Thoughts on Autonomy and Equality in Relation to Roe v. Wade, 63 N.C. L. REV. 375, 383 (1985) (noting that a woman's ability to control her reproductive capacity is equivalent to her ability to take autonomous charge of her life).

4 See generally COOK ET AL., supra note 1; REPRODUCTIVE HEALTH AND HUMAN RIGHTS (Laura Reichenbach \& Mindy Jane Roseman eds., 2009) (discussing how the understanding of reproductive rights has evolved on an international scale).

5 See, e.g., International Covenant on Economic, Social and Cultural Rights, art. 12(2)(a), opened for signature Dec. 16, 1966, 993 U.N.T.S. 3, 8 (entered into force Jan. 3, 1976) [hereinafter ICESCR] (requiring "reduction of the stillbirth-rate and of infant mortality and for the healthy development of the child."); Convention on the Elimination of All Forms of Discrimination Against Women, opened for signature Dec. 18, 1979, art. 12(2), 1249 U.N.T.S. 13, 19 (entered into force Sept. 3, 1981) [hereinafter CEDAW] (ensuring for women "appropriate services in connection with pregnancy, confinement and the post-natal period, granting free services where necessary, as well as adequate nutrition during pregnancy and lactation"); see also discussion infra Part II.B.1.

6 See COOK ET AL., supra note 1, at 148-215 (describing how various human rights provisions apply to reproductive health).

7 A number of international documents have stated that reproductive health is a human right, most notably the Programmme of Action of the International Conference on Population and Development. See Int'l Conference on Population \& Dev., Cairo, Egypt, Sept. 5-13, 1994, Programme of Action, ch. 2, princ. 8, A/CONF.171/13 (Oct. 18, 1994) [hereinafter ICPD Programme of Action]. 
reproductive health can serve as an organizing principle for human rights protections. In this context, the Article will define a set of reproductive health rights that comprise the human right to reproductive health. Reproductive health rights are human rights that uphold reproductive health and well-being, including rights that protect the ability to decide whether and when to reproduce, guarantee reasonable access to adequate reproductive health services, minimize social conditions that may undermine reproductive health and related decisions, and strengthen health and social systems to support good reproductive health. In short, realizing these reproductive health rights and the underlying conditions necessary to sustain them will provide the foundation for a robust right to reproductive health.

The human right to reproductive health exists at the intersection of discourses about reproductive rights and the right to health. ${ }^{8}$ However, the human right to reproductive health is not merely a subcomponent of the right to health or one of several rights included under the rubric of reproductive rights. Rather, the human right to reproductive health presents a unique conceptualization of human rights protection focused on considerations of reproductive health and the fulfillment of factors necessary to support good reproductive health.

The focus on a human right to reproductive health in this Article diverges to some extent from a common approach taken by many reproductive rights scholars and courts in the United States and elsewhere, which I will refer to as the reproductive rights model. This model-and the jurisprudential precedents it often follows-centers its analysis on rights protecting the decisional autonomy of women in matters of reproduction. ${ }^{9}$ By presenting a contrasting model that

8 See COOK ET AL., supra note 1, at 255-393 (examining the intersection of reproductive health and human rights through a number a reproductive health examples, including sexual assault and emergency contraception, involuntary sterilization, HIV drug research and testing, and selective abortions).

9 See, e.g., Ruth Bader Ginsburg, Speaking in a Judicial Voice, 67 N.Y.U. L. Rev. 1185 (1992); Reva Siegel, Reasoning from the Body: A Historical Perspective on Abortion Regulation and Questions of Equal Protection, 44 STAN. L. REv. 261 (1992) [hereinafter Siegel, Reasoning from the Body]; Reva B. Siegel, Sex Equality Arguments for Reproductive Rights: Their Critical Basis and Evolving Constitutional Expression, 56 EMORY L.J. 815 (2007); Robin West, From Choice to Reproductive Justice: De-Constitutionalizing Abortion Rights, 188 YALE L.J. 1394 (2009). But see Reilly Anne Dempsey \& Benjamin Mason Meier, Going Negative: How Reproductive Rights Discourse Has Been Altered from a Positive to a Negative Rights Framework in Support of "Women's Rights," in WOMEN's GLOBAL HEALTH AND HUMAN RiGHTS 83, 84 (Padmini Murthy \& Clyde Lanford Smith eds., 2010) (discussing the limits of a reproductive rights discourse that only discusses negative rights); Beth A. Burkstrand-Reid, The Invisible Woman: Availability and Culpability in Reproductive Health Jurisprudence, $81 \mathrm{U}$. COLO. L. REV. 97 (2010) (examining the methods by which U.S. courts inadequately consider 
primarily focuses on reproductive health-categorized here as the right to health model - this Article highlights specific human rights aspects of reproductive health that are often overlooked or undervalued in reproductive rights and human rights discourses. Both of these models ultimately provide useful, albeit different, conceptions of reproductive health rights that can be combined to more fully develop a dynamic understanding of reproductive health as a human right.

Part I of the Article examines the global state of reproductive health and outlines some of the prodigious challenges that exist worldwide due to the persistence of circumstances and policies that undermine positive reproductive health outcomes and the protection of human rights. Next, Part II describes and compares the reproductive rights model and the right to health model. These two models share many common features in the ways they contextualize reproductive health rights, yet they exhibit substantive differences in scope and emphasis. Specifically, the reproductive rights model primarily considers the decisional aspects of human rights, while the right to health model focuses on the foundational aspects of human rights. Examining and contrasting these two models reveals that each have their strengths and limitations. Furthermore, the prevailing models for linking reproduction and human rights have not sufficiently or consistently accounted for reproductive health.

In the next section of the Article, Part III, the discussion turns to reconciling the two models to define reproductive health rights. Building on this definition, the Article explores some of the implications of this broader conception of reproductive health as a human right and calls for the continued development of a robust understanding of the human right to reproductive health grounded in the realization of the underlying determinants of health. ${ }^{10}$ This discussion considers the advantages of, and potential problems with, applying a more broadly framed notion of reproductive health to support reproductive rights claims. Part III also addresses some of

women's health in cases related to abortion, contraception, and childbirth); COOK ET AL., supra note 1 , at 255-393 (examining the relationship between various human rights and reproductive health).

10 The discussion of underlying determinants of health is based primarily on these determinants as defined in General Comment 14 to the International Covenant on Economic, Social, and Cultural Rights. See U.N. Comm. on Econ., Soc. and Cultural Rights [CESCR], The Right to the Highest Attainable Standard of Health: General Comment No. 14, II 4, U.N. Doc. E/C.12/2000/4 (Aug. 11, 2000) [hereinafter General Comment 14]; see also AnnJanette Rosga \& Margaret L. Satterthwaite, The Trust in Indicators: Measuring Human Rights, 27 BERKELEY J. INT'L L. 253 (2009) (discussing the development and usage of human rights indicators). 
the challenges facing efforts to enhance the salience and legal enforceability of reproductive health rights. Four areas receive consideration: efforts to increase the prominence of reproductive health rights in legal and policy discourses at the global and national levels; efforts to advance the development of substantive norms related to reproductive health rights; efforts to support and expand the legal recognition and justiciability of reproductive health rights; and efforts to develop and utilize redundant human rights and public health infrastructures that may be available to support and enforce reproductive health rights. ${ }^{11}$ In order to advance reproductive health rights in each of these four areas, constraints on political will and social counter-pressures may need to be surmounted.

\section{THE GLOBAL STATE OF REPRODUCTIVE HEALTH}

In order to truly understand the global context of reproductive health rights, it is first necessary to consider public health statistics measuring reproductive health indicators. ${ }^{12}$ As the facts and figures that follow demonstrate, the lack of an adequate level of reproductive health is a widespread problem globally, particularly in the developing world. Moreover, deficiencies in reproductive health indicators are largely conditions that can be alleviated with a combination of better access to health services, improvement in economic and social conditions, and increased protection of human rights related to reproductive health. The following sections summarize data on six key areas of reproductive health: maternal mortality; access to reproductive health services, family planning services, and abortion services; and the prevalence of female genital

11 See generally Lance Gable, The Proliferation of Human Rights in Global Health Governance, 35 J.L. MED. \& ETHICS 534 (2007) (discussing the expansion of human rights discourse and application related to health govemance).

12 The World Health Organization has identified seventeen reproductive health indicators, which cover a wide range of factors relevant to assessing the state of reproductive health. The indicators are: (1) total fertility rate; (2) contraceptive prevalence; (3) maternal mortality ratio; (4) percentage of women attended by health personnel during pregnancy; (5) percentage of births attended by skilled health personnel; (6) number of facilities with basic obstetric care; (7) number of facilities with comprehensive obstetric care; (8) perinatal mortality rate; (9) percentage of live births with low birth weight; (10) positive syphilis serology in pregnant women; (11) percentage of anemia in pregnant women; (12) percentage of obstetric admissions owing to abortion; (13) prevalence of women with genital cutting; (14) percentage of women who report trying for a pregnancy for two years or more; (15) incidence of urethritis in men; (16) HIV prevalence in pregnant women; and (17) knowledge of HIV-prevention practices. World Health Organization Second Interagency Meeting, Geneva, Switz., July 17-19, 2000, Reproductive Health Indicators for Global Monitoring, at 20-23, WHO/RHR/01.19 (2001), available at http://whqlibdoc.who.int/hq/2001/WHO_RHR_01.19.pdf; see also, Ritu Sadana, Definition and Measurement of Reproductive Health, 80 BULL. WORLD HEALTH ORG. 407 (2002) (suggesting criteria for measuring reproductive health). 
cutting and sexually transmitted infections. ${ }^{13}$ Taken together, the persistence of unsatisfactory reproductive health indicators across these key areas underscores the need for continued efforts to focus on reproductive health within international human rights and development initiatives.

\section{A. Maternal Mortality}

Maternal mortality remains staggeringly high. According to the World Health Organization, 1,500 women die from complications of pregnancy or childbirth every day, totaling 536,000 maternal deaths in 2005 alone.$^{14}$ Most of these deaths are concentrated in developing countries, and most were preventable. ${ }^{15}$ There are enormous disparities in health outcomes between developing and developed countries. For example, complications of pregnancy and childbirth kill one out of six women in Sierra Leone and Afghanistan, while in Sweden the maternal mortality rate is only one woman per 29,800 births. ${ }^{16}$

In other developing countries, efforts to reduce maternal mortality have had success. The maternal mortality ratio in Sri Lanka, for example, decreased from 92 per 100,000 live births in 2000 to 58 per 100,000 live births in $2005 .{ }^{17}$ Sri Lanka succeeded in achieving these significant reductions in maternal mortality in part by increasing access to skilled health personnel during delivery, increasing the number of hospital births, and expanding a system of trained

13 This section highlights these six reproductive health indicators because together they provide a good cross-sectional assessment of the deficiencies in different areas of reproductive health. However, as the full list of reproductive health indicators identified by the WHO indicates, a broad understanding of reproductive health incorporates many health-related and social indicators.

14 WHO, Making Pregnancy Safer: Maternal Mortality, http://www.who.int/making _pregnancy_safer/topics/maternal_mortality/en/index.html (last visited May 10, 2010) [hereinafter WHO, Maternal Mortality] ("Every day, 1500 women die from pregnancy- or childbirth-related complications. In 2005, there were an estimated 536000 maternal deaths worldwide. Most of these deaths occurred in developing countries, and most were avoidable."). As the Executive Director of the United Nations Population Fund (UNFPA), Thoraya Ahmed Obaid has stated, this number roughly translates into one woman dying during pregnancy or in childbirth every single minute. Thoraya Ahmed Obaid, Executive Dir. of the UNFPA, Saving Women's Lives, Lecture at Smith College (Mar. 26, 2003), available at http://www.unfpa.org/public/home/news/pid/3655.

15 United Nations, THE MILlenNium DeVELOPMENT GOALS RePORT 2010, at 31 (2010), available at http://www.un.org/millenniumgoals/pdf/MDG\%20Report\%202010\%20En \%20r15\%20-low\%20res\%2020100615\%20-.pdf [hereinafter MDGs REPORT 2010].

16 20th Anniversary: Safe Motherhood Initiative-Renewed Commitments for Maternal and Newborn Health Survival, MAKING PREgNANCY SAFER (World Health Org., Geneva, Switz.), Nov. 2007, at 1, 8, available at http://www.who.int/making_pregnancy_safer/ documents/newsletter/mps_newsletter_issue5.pdf.

17 Id. at 1. 
midwives for home deliveries. This has resulted in over $90 \%$ of births taking place in the hospital, and $97 \%$ of deliveries being attended by a skilled birth attendant. ${ }^{18}$ Sri Lanka also expanded antenatal care and emergency obstetric care. ${ }^{19}$ Unfortunately, Sri Lanka remains an outlier among developing countries, many of which continue to have high rates of maternal mortality. ${ }^{20}$

\section{B. Access to Reproductive Health Services}

Access to reproductive health care and related services remains sparse in many parts of the world. Prenatal care may not be available or accessible. In developing countries, the percentage of pregnant women who do not have access to or contact with skilled health personnel prior to delivery is estimated at $20 \%{ }^{21}$ Further, "less than two thirds (62\%) of women in developing countries receive assistance from a skilled health worker when giving birth." 22 In developed nations, by contrast, skilled health workers attend $99 \%$ of deliveries. ${ }^{23}$

\section{Family Planning Services}

Data indicate increasing access to family planning services in many countries. Indeed, the United Nations' 2008 Millennium Development Goals Report suggests that the "unmet need for family planning . . . has declined in most countries." ${ }^{24}$ This means that women in these countries who wish to delay or avoid having children increasingly have access to contraception. Nevertheless, access to contraceptives remains limited in many parts of the world. The United Nations Population Fund (UNFPA) estimates that 200 million women worldwide "want to delay or prevent pregnancy but are not using effective contraception., ${ }^{25}$ Limitations on access to contraceptives

18 NAT'L COUNCIL OF ECON. DEV, OF SRI LANKa, MILlENNIUM DEVElopMENT GoAlS COUNTRY REPORT 2005: SRI LANKA 61-64 (2005), available at http://www.mdg.lk/inpages /mdg_reports/2005/mdg_report_2005.htm.

${ }^{19}$ Id. at 1.

20 MDGs REPORT 2010, supra note 15, at 30-38.

21 See id. at 32.

22 WHO, Maternal Mortality, supra note 14. In some of these countries, the figure is only between ten and twelve percent. United Nations Population Fund, Skilled Attendance at Birth, http://www.unfpa.org/public/mothers/pid/4383 (last visited May 10, 2010); see also MDGs REPORT 2010, supra note 15 , at 31 (providing the percentage of deliveries attended by skilled health personnel by region).

23 MDGs REPORT 2010, supra note 15, at 31.

24 UNITED NATIONS, THE MILLENNIUM DEVELOPMENT GOALS REPORT 2008, at 27 (2008) [hereinafter MDGs REPORT 2008], available at http:/www.un.org/millenniumgoals/pdf/The \%20Millennium\%20Development\%20Goals\%20Report\%202008.pdf.

${ }_{25}$ United Nations Population Fund (UNFPA), A Global Need for Family Planning (2008), http://www.unfpa.org/m/planning/mediakit/docs/new_docs/sheetl-english.pdf. (last 
impact more than just the ability to engage in family planning; these limitations also give rise to additional health risks for pregnant women, arising from medical complications from unwanted pregnancies and the potential for increased exposure to sexually transmitted infections, including HIV. ${ }^{26}$ The UNFPA projects that effective means of access to contraception could help women avoid one in three deaths related to pregnancy and childbirth. ${ }^{27}$

Only one in five married women in Africa use modern contraception, and the proportion drops to less than one in twenty women in some areas of the continent. ${ }^{28}$ Contraception use correlates closely to economic status, and the unmet need for family planning is highest among the poorest households. ${ }^{29}$ Indeed, according to the UNFPA, "[o]n average, the poorest women are four times less likely to use contraception than the wealthiest: In some countries, the rate is 12 times lower." 30

\section{Abortion Services}

Access to abortion services varies significantly in different countries, ranging from complete prohibition of the practice to pregnancy termination on demand. ${ }^{31}$ Unsafe abortions are performed an estimated 20 million times per year in the least developed countries, resulting in an estimated 68,000 maternal deaths. ${ }^{32}$ In

visited Aug. 28, 2010)

26 See UNITED NATIONS POPULATION FUND, DONOR SUPPORT FOR CONTRACEPTIVES AND CONDOMS FOR STI/HIV PREVENTION 2009, at 8-9 (2009), available at http://www.unfpa .org/webdav/site/global/shared/documents/publications/2010/dsr_2009.pdf

27 United Nations Population Fund, Contraceptives Save Lives, at 2 (2008), http://www.unfpa.org/webdav/site/global/shared/safemotherhood/docs/contraceptives_factsheet _.en.pdf (last visited Aug. 28, 2010)

28 United Nations Population Fund, State of World Population 2005, Reproductive Health Fact Sheet, http://www.unfpa.org/swp/2005/presskit/factsheets/facts_rh.htm (last visited May 10, 2010) [hereinafter UNFPA Reproductive Health Fact Sheet].

29 See MDGs REPORT 2008, supra note 24, at 27 ("[I]n sub-Saharan Africa, nearly one in four married women has an unmet need for family planning, and the rise in contraceptive use has, on average, barely kept pace with the growing desire to delay or limit births. This contributes to the continuing high fertility rate in that region and has undermined related goals, such as reducing child mortality, hunger and malnutrition, and increasing primary education enrolment [sic]. In all regions, this unmet need is highest among the poorest households.").

30 UNFPA Reproductive Health Fact Sheet, supra note 28.

31 WORLD Health ORganization, UnSaFe abortion: Global and Regional ESTIMATES OF THE INCIDENCE OF UNSAFE ABORTION AND ASSOCIATED MORTALITY IN 2003, at 2 (2003), available at http://whqlibdoc.who.int/publications/2007/9789241596121_eng.pdf [hereinafter UNSAFE ABORTION].

32 United Nations Population Fund, Fact Sheet: Motherhood and Human Rights (Aug. 2009), http://www.unfpa.org/public/cache/offonce/factsheets/pid/3851\#contraception; see also WHO, Maternal Mortality, supra note 14 ("Complications after unsafe abortion cause $13 \%$ of matemal deaths."). 
addition, thousands of pregnant women face health complications resulting from unsafe abortions. ${ }^{33}$ The health consequences to a woman from an unsafe abortion can be severe depending on the method of induced abortion used and may include sepsis, hemorrhage, trauma to reproductive organs, or even death. ${ }^{34}$ Additionally, the frequency of complications from unsafe abortions may use resources that would otherwise be available for maternity or other health care purposes. ${ }^{35}$

\section{E. Prevalence of Female Genital Mutilation}

The practice of female genital mutilation (FGM) - the ritualistic cutting and scarring of the genitals of women and young girlsremains a widespread practice in some parts of Africa and the Middle East. ${ }^{36}$ An estimated 100 to 140 million girls and women are affected worldwide, and three million girls in Africa are subjected to different variations of this procedure each year. ${ }^{37}$ FGM has potentially serious reproductive health consequences for girls and women, including more frequent infections of the reproductive tract, infertility, and prolonged or obstructed childbirth. ${ }^{38}$ This practice violates a number of human rights in addition to the right to reproductive health, including the rights to avoid inhuman and degrading treatment and discrimination. ${ }^{39}$

33 United Nations Population Fund, State of World Population 2004, Maternal Health, Post-Abortion Care, http://www.unfpa.org/swp/2004/english/ch7/pagel1.htm (last visited May 10,2010 ) ("In sub-Saharan Africa, up to 50 per cent of gynaecological beds are occupied by patients with abortion complications.").

34 UNSAFE ABORTION, supra note 31, at 5. Methods of unsafe abortion "may involve insertion of a solid object .... into the uterus; a dilatation and curettage procedure performed improperly by an unskilled provider; ingestion of harmful substances; exertion of external force; or misuse of modern pharmaceuticals." Id.

35 Id.

36 See Hope Lewis, Female Genital Mutilation and Female Genital Cutting, in 2 ENCYCLOPEDIA OF HUMAN RIGHTS 200, 201 (David P. Forsythe ed., 2009).

37 World Health Org., Female Genital Mutilation, http://www.who.int/mediacentre /factsheets/fs241/en/index.html (last visited May 10, 2010).

38 Id.; see also WHO Study Group on Female Genital Mutilation and Obstetric Outcome, Female Genital Mutilation and Obstetric Outcome: WHO Collaborative Prospective Study in Six African Countries, 367 LANCET 1835, 1841 (2006) ("FGM is therefore likely to lead to substantial additional cases of adverse obstetric outcome in many countries, with the estimates presented here suggesting that FGM could cause one to two extra perinatal deaths per 100 deliveries to African women who have had FGM.").

39 See Lesley Stone, Lance Gable \& Tara Gingerich, When the Right to Health and the Right to Religion Conflict: A Human Rights Analysis, 12 MiCH. ST. J. INT'L L. 247, 296-304 (2004) (describing human rights violations related to female genital mutilation). 


\section{F. Sexually Transmitted Infections}

The rate of sexually transmitted infections in the population provides another crucial indicator of reproductive health. Not only do sexually transmitted infections often produce negative reproductive health outcomes, these infections have a close link to sexual and reproductive practices due to the means by which they are spread. HIV infection of newborns through mother-to-child transmission continues to occur due to insufficient efforts to provide access to adequate treatment and health information. ${ }^{40}$ In sub-Saharan Africa, "less than $10 \%$ of pregnant women infected with HIV receive interventions to reduce [mother-to-child transmissions]., ${ }^{, 41}$ Complications from HIV and AIDS also contribute to maternal mortality. ${ }^{42}$ The deleterious effects of sexually transmitted infections on reproductive health are not limited to HIV. Syphilis infection is estimated to cause 492,000 additional stillbirths and perinatal deaths annually. ${ }^{43}$

\section{G. Reproductive Health Indicators: Implications for Human Rights}

Considering the health and social impacts revealed by these reproductive health indicators, two salient points emerge. First, across many areas of reproductive health, substantial work needs to be done to improve health outcomes, increase access to necessary services and information, and strengthen the linkage between health and human rights to support better health outcomes. Second, despite the promise offered by rights-based approaches to reduce these problems, many countries have not employed or supported rights-based strategies in these areas. To some extent this stems from diverging understandings of the concept and content of the human right to reproductive health. The next sections examine the conceptual underpinnings of differing rights models as applied to reproductive health, the development of these models, and their limitations.

40 LANCE GaBle ET AL., LEGal ASPECTS OF HIV/AIDS: A GUIDE FOR POLICY AND LAW REFORM 7-9, 141-43 (2007) (discussing legal challenges related to mother-to-child HIV transmission and to upholding reproductive rights in the context of HIV).

41 World Health Org., Dep't of Making Pregnancy Safer, Annual Report 2006, at 28, WHO/MPS/07.08 (2007), available at http://whqlibdoc.who.int/hq/2007/WHO_MPS_07 .08.pdf [hereinafter Making Pregnancy Safer, Annual Report 2006].

42 MDGS REPORT 2010, supra note 15, at 31.

43 Making Pregnancy Safer, Annual Report 2006, supra note 41, at 18. 


\section{CONCEPTUALIZING REPRODUCTIVE HEALTH RIGHTS: THE REPRODUCTIVE RIGHTS MODEL AND THE RIGHT TO HEALTH MODEL}

Reproductive health rights exist at the convergence of two human rights models: the reproductive rights model and the right to health model. These models are not exclusive of one another and have many aspects in common. Indeed, their differences arise mostly from distinctions in emphasis and approach. Nevertheless, these distinctions, described in detail below, often complicate the recognition of reproductive health rights, as well as their attainment. Charting the conceptual overlap between the reproductive rights model and right to health model requires an understanding of the development of these models under international human rights law and theory.

The reproductive rights model and the right to health model share several salient features. First, both models adopt the human rights paradigm, a fundamental conception that certain rights apply to all humans by virtue of their humanity and that these rights can be claimed from governments, which have a legal obligation to uphold them. ${ }^{44}$ Applying rights discourse to matters of reproductionwhether pertaining to reproductive decision making or reproductive health-bolsters the legal and moral validity of claims for reproductive health and helps to elucidate the substantive content of reproductive health rights. Second, both models consider the relevance of a wide array of rights as they apply to reproduction and recognize that the interrelationship of human rights is complex and consequential for reproductive health. ${ }^{45}$ Third, both the reproductive rights model and the right to health model can be said to encompass reproductive health rights. Yet viewing reproductive health rights as a component of the reproductive rights model produces a different conception than viewing it as a component of the right to health model.

The variance in perspectives between the models builds on the historical divergence between reproductive rights and the right to health. Rather than dividing these models along the typical lines of negative and positive rights, this Article instead delineates these

44 See LOUIS HENKIN, THE AGE OF RIGHTS 20-21 (1990) (addressing the fundamental nature of human rights). Of course, governments often violate rights or refuse to sign and ratify international human rights treaties that would impose obligations to protect human rights.

45 World Conference on Human Rights, June 14-25, 1993, Vienna Declaration and Programme of Action, II 5, U.N. Doc. A/CONF.157/23 (July 12, 1993) [hereinafter Vienna Declaration] ("All human rights are universal, indivisible and interdependent and interrelated."). 
models according to whether they focus on decisional or foundational aspects of human rights.

Reproductive rights, particularly as they have been framed in developed countries, have typically revolved around the protection of the rights of an individual to make autonomous reproductive decisions, grounded in civil and political rights to privacy, liberty, equality, autonomy, and dignity. ${ }^{46}$ Consequently, the reproductive rights model favors efforts to uphold decisional aspects of human rights as applied to reproduction, i.e., the rights, conditions, and determinants that support the ability of an individual to make autonomous reproductive decisions without coercion. ${ }^{47}$

The right to health, by contrast, has developed primarily as an economic, social, and cultural right, with an attendant focus on the provision of affirmative access to health services and, more recently, on guarantees to uphold the underlying determinants of health. ${ }^{48}$ However, international documents and scholarly analysis have clearly recognized negative rights within the right to health as well. ${ }^{49}$ Therefore, it is helpful to consider the right to health model as one centered on upholding foundational aspects of human rights, in other words, the rights, conditions, and determinants that provide the necessary foundations upon which the right to reproductive health can be realized. ${ }^{50}$ The foundational aspects of human rights protect the ability to exercise human rights and actualize their content, and include equal protection provisions; guarantees of access to health services and education; support of property rights; and protection from violence and discrimination, among other rights.

Reproductive health rights thus sit at the junction of these two evolving models (see Figure 1). In addition, reproductive health rights are also rooted in the practice and concepts of the field of reproductive health. This field has not historically oriented itself with human rights and has only gradually moved toward a right-based paradigm over the past fifteen years or so. ${ }^{51}$ In so doing, reproductive

46 See Dempsey \& Meier, supra note 9, at 83-84 (criticizing the negative rights focus of reproductive rights discourse).

47 See discussion infra Part II.A.

48 When the rights found in the Universal Declaration of Human Rights were divided into civil and political rights and economic, social, and cultural rights, the right to health was included in the International Covenant of Economic, Social and Cultural Rights. ICESCR, supra note 5 , art. 12.

49 General Comment 14, supra note 10, 98 (identifying both freedoms and entitlements within the Right to Health found in Article 12 of the ICESCR); see also B. Jessie Hill, Reproductive Rights as Health Care Rights, 18 COLUM. J. GENDER \& L. 501, 531-37 (2009) (identifying the negative rights aspect of the right to health in United States jurisprudence).

so See discussion infra Part II.B.

51 The International Conference on Population and Development was the turning point in 
health advocates working at the international and national levels have increasingly adopted the tools and terminology of human rights in laws and policies designed to improve reproductive health outcomes. ${ }^{52}$ Since embracing the human rights paradigm, reproductive health advocates have drawn on both the reproductive rights and right to health models. Conceptualizing reproductive health as a human right necessitates understanding how reproductive health rights fit within each of these models and the limitations of these models in fully defining reproductive health rights. The following sections outline the conceptual and normative development of reproductive health rights within the reproductive rights and right to health models, respectively.

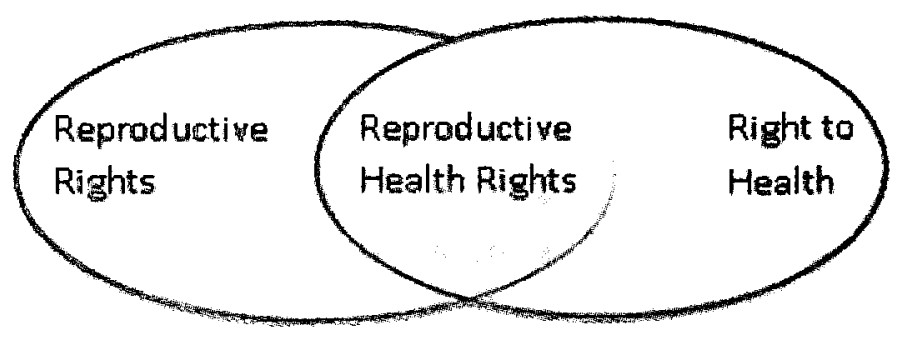

Figure 1. The convergence of reproductive rights, the right to health, and reproductive health rights.

\section{A. The Reproductive Rights Model}

Reproductive rights have developed over many years due to the impassioned advocacy and incremental legal advancements of two interrelated movements: national and transnational women's rights movements and the international human rights movement. Both of

this transition. See, e.g., Mindy Jane Roseman \& Laura Reichenbach, Global Reproductive Health and Rights: Reflecting on ICPD, in REPRODUCTIVE HEALTH AND HUMAN RIGHTS, supra note 4 , at 4 ("Prior to ICPD, the international lexicon and national policies addressing population focused on the control of fertility, understood entirely as women's fertility . . .."); COOK ET AL., supra note 1, at 154-56 (explaining the transition from laws criminalizing women's reproduction and sexuality to laws promoting individuals' interest in reproductive health to laws emphasizing human rights and justice).

52 The ICPD Programme of Action uses human rights terminology. ICPD Programme of Action, supra note 7, I 7.2. Many subsequent international reports use this terminology as well. See, e.g., United Nations Population Fund, STATE OF WoRLd POPUlation 2005: THE PROMISE OF EQUALITY: GENDER EQUTTY, REPRODUCTIVE HEALTH AND THE MILLENNIUM DEVELOPMENT GOALS (2005) [hereinafter UNFPA, STATE OF WORLD POPULATION 2005]; UNITED NATIONS POPULATION FUND, A HUMAN RIGHTS-B ASED APPROACH TO PROGRAMMING (2010). 
these movements have advanced notions of individual freedom and dignity for women, and the recognition and realization of equality across genders. ${ }^{53}$ In addition, these movements have often developed in parallel and drawn upon each other's ideas. National women's rights movements, for instance, have frequently embraced international human rights principles to advance their goals, working to secure ratification of international human rights treaties in their countries and supporting efforts to revise national laws to secure recognition of reproductive rights. ${ }^{54}$ Similarly, transnational women's rights advocates have participated and influenced the development of international human rights instruments and reports. ${ }^{55}$ Reproductive rights have been featured in many of the international human rights treaties and have been a cornerstone of global efforts to improve health, as well as a touchstone for contentious political debates that implicate the most personal of human decisions.

\section{The Development of the Reproductive Rights Model Through the Women's Rights Movement}

Women's rights movements at national and international levels have contributed to the development of the reproductive rights model and helped to establish the legal and political understandings necessary to uphold this model. The impact of these efforts on recognition of reproductive rights varies significantly around the world. ${ }^{56}$ Reproductive rights advocates in the women's rights movement have pursued simultaneous development of legal recognition of reproductive rights in international, national, and sub-national jurisdictions. These efforts may use the language of human rights as support for legal and ethical claims to reproductive rights, or they may turn to ethical or constitutional theories to support recognition of reproductive rights. ${ }^{57}$

53 See generally SISTERHOOD IS POWERFUL: AN ANTHOLOGY OF WRITINGS FROM THE WOMEN'S LIBERATION MOVEMENT (Robin Morgan ed., 1970); HuMAN RigHTS OF WOMEN: NATIONAL AND INTERNATIONAL PERSPECTIVES (Rebecca J. Cook ed., 1994); STEVEN M. BUECHLER, WOMEN'S MOVEMENTS IN THE UNITED STATES: WOMAN SUFFRAGE (1990).

54 See Beth A. Simmons, Mobilizing FOR Human Rights 222-231 (2009) (discussing the effects of CEDAW ratification on national-level recognition of reproductive rights).

${ }^{55}$ See Elisabeth Jay Friedman, Gendering the Agenda: The Impact of the Transnational Women's Rights Movement at the UN Conferences of the 1990s, 26 WOMEN'S STUD. INT'L F. 313 (2003) (discussing the impact of women's rights advocates on international human rights meetings); Elisabeth Friedman, Women's Human Rights: The Emergence of a Movement, in WOMEN's Rights, HuMAN RIGHTS: INTERNATIONAL FEMINIST PERSPECTIVES 18, 18-35 (Julie Peters \& Andrea Wolper eds., 1995).

56 See SIMMONS, supra note 54 at 222-31.

57 Even where reproductive rights were being sought in national or sub-national settings, and the language of human rights was instead replaced with language referencing civil rights or 
In the United States, for example, reproductive rights jurisprudence has rarely invoked explicitly international human rights obligations, instead favoring the use of constitutional arguments to challenge limitations on reproductive rights. ${ }^{58}$ This strategy is understandable given the lack of established international human rights standards when many of the initial legal challenges were being advanced and the historical reluctance of United States courts to apply international law to resolve domestic constitutional issues. ${ }^{59}$

Beginning in the 1960s, women's rights advocates supported successful legal challenges to state laws that impeded a woman's right to make reproductive health decisions or to access reproductive health services. In Griswold v. Connecticut ${ }^{60}$ the Supreme Court invalidated a state law prohibiting access to contraception on the premise that such a restriction violated a constitutionally protected right to privacy. ${ }^{61}$ Several years later, in the landmark 1973 decision in Roe v. Wade, ${ }^{62}$ the Court recognized that this right of privacy extended to a woman's decision to terminate her pregnancy. ${ }^{63}$ Roe and its progeny have since dominated the reproductive rights discussion in the United States.

The legacy of abortion jurisprudence in the United States is mixed with respect for protecting women's reproductive rights and reproductive health. Subsequent cases have both putatively expanded the constitutional bases on which women's reproductive rights and freedoms are grounded ${ }^{64}$ and limited the actual ability of women to exercise those rights and freedoms. ${ }^{65}$ The treatment of reproductive

constitutional rights, the essential rights arguments were often the same.

58 All of the major cases relating to women's reproductive health decisions or access to reproductive health services make constitutional rights arguments under the United States Constitution rather than invoking international human rights law. See infra notes 60-68.

59 See generally Frank I. Michelman, Integrity-Anxiety?, in AMERICAN EXCEPTIONALISM AND HUMAN RIGHTS 241 (Michael Ignatieff ed., 2005) (explaining the hesitancy of United States judges to apply international human rights law to cases in domestic courts).

60381 U.S. 479 (1965).

${ }^{61}$ Id. at 481-86.

62410 U.S. 113 (1973).

63 Id. at 147-64.

64 See, e.g., Planned Parenthood of Se. Pa. v. Casey, 505 U.S. 833, 851, 856, 857 (1992) (discussing the application of rights to privacy, to equal participation "in the economic and social life of the Nation," and to "bodily integrity" as grounds for affording protection to decisions related to procreation and reproduction); see also Hill, supra note 49, at 506-17 (2009) (discussing the recognition of different rights supporting a woman's decision to terminate a pregnancy and suggesting the existence of a negative right to health care within U.S. abortion jurisprudence).

65 See, e.g., Gonzales v. Carhart, 550 U.S. 124, 168 (2007) (upholding the federal Partial-Birth Abortion Ban Act); Casey, 505 U.S. at 845-46, 869-91 (reaffirming the fundamental holding of Roe $v$. Wade, but upholding restrictions on access to abortion services 
health within these decisions varies. Reproductive health outcomes have been used in these decisions to justify recognition of a woman's right to make reproductive decisions, including termination of a pregnancy, and to restrict access to abortion services under "woman-protective" restrictions. ${ }^{66}$ In addition, these decisions have generated strong critiques by legal scholars who suggest that the prominent role of medical judgment in exercising reproductive rights undermines the equality of women with regard to abortion decision making. ${ }^{67}$

The history of reproductive rights also includes efforts by women's rights movements to achieve gender equality across all areas of society, including areas relevant to reproduction. ${ }^{68}$ These efforts met with mixed legal and policy success. In the United States, attempts to enact an Equal Rights Amendment stalled after having initial momentum in the $1970 \mathrm{~s} .{ }^{69}$ Other developed countries were more successful in enacting legislative protections for gender equality, but worldwide measures of gender equality vary greatly. ${ }^{70}$

\section{The Development of the Reproductive Rights Model Through the Human Rights Movement}

From the beginning of the human rights movement, issues related to women's rights and reproductive rights have been recognized in international human rights documents with varying levels of prominence. Article 25 of the Universal Declaration of Human Rights

under Pennsylvania law).

66 See Reva B. Siegel, Dignity and the Politics of Protection: Abortion Restrictions Under Casey/Carhart, 117 YALE L.J. 1694, 1735-66 (2008) (discussing the varying uses of notions of dignity and health consequences in Casey and Carhart to support restrictions on abortion).

67 See, e.g., Laurence H. TRIBE, ABortion: THE Clash of Absolutes (1990); Ginsburg, Speaking in a Judicial Voice, supra note 9; Siegel, Reasoning from the Body, supra note 9; West, supra note 9.

68 See generally RICKIE SOLINGER, PREgnANCY AND POWER: A SHORT HISTORY OF REPRODUCTIVE POLITICS IN AMERICA (2005).

69 See, e.g., MARY FRANCES BERRY, WHY ERA FAILED (1986) (describing the failure of

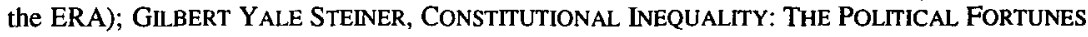
OF THE EQUAL RIGHTS AMENDMENT (1985) (same); Francis William O'Brien, The Equal Rights Amendment: Is There a Life Hereafter?, 35 OKLA. L. REV. 73 (1982) (same). Whether the some of the substantive goals of the ERA have been achieved despite the failure of the ERA to pass has been a subject of debate. See Reva B. Siegel, Constitutional Culture, Social Movement Conflict and Constitutional Change: The Case of the De Facto ERA, 94 CAL. L. REV. 1323, 1332-39 (2006) (describing this debate).

70 See SiMMONS, supra note 54, at 212-236 (2009) (examining national adoption of gender equality legislation related to reproductive rights, education, and employment). Gender equality and female empowerment is Goal 3 of the Millennium Development Goals. Efforts to promote gender equality under the MDGs has focused primarily on equality in education, workplace, and political settings. See MDGs REPORT 2010, supra note 15, at 20-25. 
(UDHR), the foundational document of the modern international human rights system, guarantees that "[m]otherhood and childhood are entitled to special care and assistance. All children, whether born in or out of wedlock, shall enjoy the same social protection.",71 Although reproductive rights are inferred by this reference to motherhood, the UDHR did not provide direct protection for reproductive rights under its understanding of the right to health. More broadly, the UDHR does protect other women's rights that support reproductive rights, including rights to privacy, ${ }^{72}$ to consent to and have equal rights in marriage, ${ }^{73}$ to be free from discrimination based on gender, ${ }^{74}$ and to not be subjected to torture or cruel, inhuman, or degrading treatment or punishment. ${ }^{75}$

The subsequent binding international human rights covenants divided human rights into two categories: civil and political rights, and economic, social, and cultural rights. The International Covenant on Civil and Political Rights (ICCPR) ${ }^{76}$ contained so-called negative rights, such as rights to life, liberty, privacy, fair trial procedures, antidiscrimination, equal protection under the law, marriage, and civic participation. ${ }^{77}$ The negative nature of these rights stemmed from the obligation they placed on government actors to refrain from imposing restrictions on an individual's ability to exercise them. The corresponding International Covenant on Economic, Social, and Cultural Rights (ICESCR) ${ }^{78}$ incorporated rights to health, education, work, social security, access to advancements in science, and adequate living standards, among others. ${ }^{79}$ Those treaties, drafted in 1966 and in force as of 1976 , created binding legal obligations on ratifying states.

The division of human rights at the international level arose from the political contentions of the Cold War era and the strong initial opposition from capitalist countries toward recognizing positive rights - affirmative obligations of the state to provide access to services. ${ }^{80}$ In reality, the categories of positive and negative rights

7 G.A. Res. 217A, at 71, art. 25, U.N. GAOR, 3d Sess., 1st plen. mtg., U.N. Doc. A/810 (Dec. 12, 1948).

12 Id. art. 12.

73 Id. art. 16.

74 See id. art. 2.

75 Id. art. 5 .

76 International Covenant on Civil and Political Rights, opened for signature Dec. 19 , 1966, 999 U.N.T.S. 171 (entered into force Mar. 23, 1976).

77 See id. arts. 6-27.

78 ICESCR, supra note 5.

79 See id. arts. 6-15.

80 Philip Alston, Putting Economic, Social, and Cultural Rights Back on the Agenda of the United States, in THE FUTURE OF HUMAN RIGHTS: U.S. POLICY FOR A NEW ERA 120, 121-23 
do not adhere tightly to the types of government obligations they engender. Civil and political rights often require affirmative government actions to protect them, including expenditures on the creation of fair judicial processes and open voting procedures. Likewise, economic, social, and cultural rights, such as the rights to health or education, can evoke obligations on the state to refrain from impeding one's health, work, or education decisions. Reproductive health services can be viewed in this way as well, giving rise to both positive and negative obligations on governments. ${ }^{81}$

The completion of the Convention on the Elimination of All Forms of Discrimination Against Women (CEDAW) ${ }^{82}$ marked a significant milestone for the recognition of women's rights generally, and reproductive rights specifically, at the international level. CEDAW's substance is primarily grounded in achieving equality for women across a range of social and political activities. The widespread adoption of CEDAW firmly established human rights protections for women on an international scale, and has resulted in substantial legal protection for rights claims based on gender discrimination.

\section{Reproductive Health Rights Under the Reproductive Rights Model}

The reproductive rights model, as articulated above, establishes a conception of reproductive health rights formulated predominantly in relation to decisional aspects of human rights. This approach has been crucial to secure women's rights to make decisions about their reproductive health in many countries without interference from the government or others. The dominant rights discourse under this model focuses on women's reproductive decisions grounded in the primarily negative human rights of decisional autonomy, bodily integrity, privacy, and dignity. ${ }^{83}$ To the extent that economic, social,

(William F. Schulz ed., 2008).

81 See Hill, supra note 49 , at 531-37 (articulating the negative right to health in the context of reproductive rights jurisprudence in the United States). Professor Hill has argued that both "South Africa and Canada have recognized in some form a 'right to health' in ways that bear partly, though not exclusively, on the abortion right." Id. at 518. Discussing Minister of Health v. Treatment Action Campaign (TAC), 2002 (10) BCLR 1033 (CC) (S. Afr.), she concludes that "South Africa has explicitly guaranteed a constitutional right to health that is understood, at least in part, as a positive entitlement to health care, including reproductive health services." Id. She contrasts the Canadian decision Chaoulli v. Québec, [2005] 1 S.C.R. 791 (Can.), stating that the Canadian court "has not gone so far as to recognize a positive constitutional right to health care." Id:; see also Colleen M. Flood, Chaoulli's Legacy for the Future of Canadian Health Care Policy, 44 OsGOODE HALL L.J. 273 (2006).

${ }^{82}$ CEDAW, supra note 5.

${ }^{83}$ See Dempsey \& Meier, supra note 9, at 83-84 (criticizing the negative rights focus of reproductive rights discourse). This narrower usage of the term reproductive rights is not 
and cultural rights are considered under this model, it is usually to support the effects of reproductive decisions.

Legislation and jurisprudence seeking social and political equality for women often adopts a negative rights approach. CEDAW, for instance, requires states to eliminate discrimination between women and men in areas as diverse as education ${ }^{84}$ employment, ${ }^{85}$ health, ${ }^{86}$ recognition before the law, ${ }^{87}$ marriage, ${ }^{88}$ and full participation in economic and social activities. ${ }^{89}$ It does not, however, require that state parties provide access to these services-presumably a state that failed to provide health care access to either men or women would not be engaged in gender-based discrimination. As a result, CEDAW has been seen as adopting a negative rights approach to women's reproductive rights. $^{90}$

Another byproduct of the prominence of the abortion debate in the field of reproductive rights-and in the political culture more generally-is that it has deflected attention from other areas of reproductive health that could provide distinct bases for expanded recognition of reproductive rights. ${ }^{91}$ Notions of reproductive freedom, reproductive justice, and reproductive health expand beyond the relatively focused debate on abortion rights to include a broader range of issues that promote good reproductive health, as well as equal and adequate access to reproductive health services.

\section{B. The Right to Health Model}

The right to health has undergone substantial conceptual and normative development over the past sixty years. The trajectory of this development has not necessarily been consistent, but the overall trend demonstrates a strong proliferation of the right to health, both in

consistent. Some entities-particularly international intergovernmental organizations-have adopted more expansive definitions of reproductive rights that adopt positive and negative rights provisions. See UNFPA, STATE OF WORLD POPULATION 2005, supra note 52, at 36 (providing a list of reproductive rights that include both civil and political rights and economic, social and cultural rights).

84 CEDAW, supra note 5, art. 10.

85 Id. art. 11.

86 Id. art. 12.

87 Id. art. 15.

88 Id. art. 16.

89 Id. art. 13.

90 See Dempsey \& Meier, supra note 9 , at 85 (suggesting that the CEDAW provisions of equality, freedom, and nondiscrimination are primarily negative in nature).

91 See Rosalind Pollack Petchesky, Reproductive Freedom: Beyond “A Woman's Right to Choose," 5 SIGNS 661 (1980) (arguing that we must evaluate the debate on reproductive rights not only from the perspective of the "woman's right to choose" but also from the broader view of its impact on societal functions). 
terms of the normative scope of the right and the structural framework within which the right applies. ${ }^{92}$ Such proliferation has been marked not only by the increasing recognition and application of the right to health at international, regional, national, and sub-national levels but also by an increased willingness of legislators and adjudicators to consider and adopt normative interpretations of the right to health across jurisdictional boundaries. ${ }^{93}$ As will be detailed below, the normative development of the right to health has included aspects of reproductive health. Based on these developments, the right to health model has incorporated an approach that focuses on upholding foundational aspects of human rights to reproductive health and ensuring that these rights and their underlying determinants are respected, protected, and fulfilled. ${ }^{94}$

\section{Evolution of the Right to Health Through International Treaty Law}

The earliest articulations of the right to health arose in the initial human rights treaties and foundational documents promulgated at the inception of the United Nations system. The WHO Constitution famously defined health as "a state of complete physical, mental and social well-being and not merely the absence of disease or infirmity." ${ }^{, 95}$ This far-reaching conception of health has been criticized for its breadth, ${ }^{96}$ but subsequent definitions of health have often reiterated its aspirational language as applied to specific areas of health. Notably, the 1994 International Conference on Population and Development's Programme of Action adopts this wording verbatim, and it broadly defines reproductive health as "a state of complete physical, mental and social well-being and not merely the absence of disease or infirmity, in all matters relating to the reproductive system and to its functions and processes., 97

The UDHR, drafted around the same time as the WHO Constitution, identified a right to health grounded less on health outcomes; instead requiring guarantees for individual access to

\footnotetext{
92 See Gable, supra note 11.

93 Id. at 536-37.

${ }_{94}$ See General Comment 14, supra note 10, पI 34-36; see also discussion infra Part II.B. 2 .

95 CONST. OF THE WORLD HEALTH ORG. pmbl., available at http://apps.who.int/gb/bd /PDF/bd47/EN/constitution-en.pdf. The WHO constitution was adopted by the International Health Conference, held in New York from June 19, 1946 to July 22, 1946, was signed on July 22, 1946 by representatives of sixty-one States, and became effective on April 7, 1948. Id. at 1 n.1 (citing 2 OFF. REC. WORLD HEALTH ORG. 100 (1948))

96 See Lawrence O. Gostin, Beyond Moral Claims: A Human Rights Approach in Mental Health, 10 CAMBRIDGE Q. HeAlTHCARE ETHICS 264, 271 (2001).

97 ICPD Programme of Action, supra note 7, II 7.2.
} 
resources necessary to achieve health. Article 25 of the UDHR states that:

1. Everyone has the right to a standard of living adequate for the health and well-being of himself and of his family, including food, clothing, housing and medical care and necessary social services, and the right to security in the event of unemployment, sickness, disability, widowhood, old age or other lack of livelihood in circumstances beyond his control.

2. Motherhood and childhood are entitled to special care and assistance. All children, whether born in or out of wedlock, shall enjoy the same social protection. ${ }^{98}$

The UDHR approach to the right to health has two noteworthy features. First, it conceives of health as the culmination of realizing underlying determinants that effect health. Second, by including specific language about motherhood, it infers the importance of reproductive rights even though Article 25 does not elaborate on this issue.

The ICESCR recognized a right to health that was in many ways narrower than the UDHR, more focused on health outcomes, and lacking any specific reference to the underlying determinants of health. ${ }^{99}$ Section 12.2(a) of the ICESCR did, however, outline a right to maternal, child, and reproductive health that encompasses "provision[s] for the reduction of the stillbirth-rate and of infant mortality and for the healthy development of the child." ${ }^{\text {"100 }}$ More importantly, the ICESCR created an international legal infrastructure to oversee and develop the right to health. The Committee on Economic, Social and Cultural Rights (CESCR), which was founded pursuant to the treaty, ${ }^{101}$ has in recent years taken the lead in developing a modernized right to health that has broadened the scope of the right.

For its part, Article 12 of the CEDAW also includes a right to health:

98 G.A. Res. 217A, at 71, art. 25, U.N. GAOR, 3d Sess., 1st plen. mtg., U.N. Doc. A/810 (Dec. 12, 1948).

99 Benjamin Mason Meier, Lance Gable, Jocelyn E. Getgen \& Leslie London, Rights Based Approaches to Public Health Systems, in RIGHTS BASED APPROACHES TO PUBLIC HEALTH 19, 20-22 (Elvira Berrochea et al. eds., 2010).

${ }^{100}$ ICESCR, supra note 5, art. 12(2)(a).

101 See id. arts. 18-25. 
1. States Parties shall take all appropriate measures to eliminate discrimination against women in the field of health care in order to ensure, on a basis of equality of men and women, access to health care services, including those related to family planning.

2. Notwithstanding the provisions of paragraph 1 of this article, States Parties shall ensure to women appropriate services in connection with pregnancy, confinement and the post-natal period, granting free services where necessary, as well as adequate nutrition during pregnancy and lactation." 102

This articulation of the right to health is, paradoxically, weaker from the perspective of protecting general health outcomes for women than the language in the ICESCR, but much stronger in the states' obligations related to reproductive health. The first clause requires equality in access to health care services between women and men (clearly an important obligation), but does not require any minimum level of services, much less provide for realization of the underlying determinants of health. The provision's second clause, however, imposes specific affirmative obligations on the state to ensure access to a range of reproductive health services, including nutrition during pregnancy and lactation. The CEDAW's description of the right to health provides a much more specific description of the content of the right to health in the context of reproductive rights and clearly imposes specific obligations on the state consistent with this right. Moreover, the treaty also provides for equal "[a]ccess to specific educational information to help to ensure the health and well-being of families, including information and advice on family planning,"103 and requires states to enact protections for both maternity leave and the workplace environment during pregnancy. ${ }^{104}$

\section{Development of Right to Health Norms}

The incremental advances in the normative development of the right to health have undergone a rapid evolution during the past ten years compared with the glacial pace of development this right experienced in preceding years. The two primary factors driving these developments are: (1) the drafting of General Comment 14 to the ICESCR; and (2) the establishment of a Special Rapportuer on the

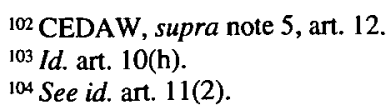


Right to the Highest Attainable Standard of Physical and Mental Health with a mandate to both oversee the implementation of the right to health and explain the scope and application of this right.

The ICESCR empowers the CESCR to promulgate General Comments to explain the content of rights contained in the Covenant. ${ }^{105}$ General Comment 14 , drafted in 2000, interprets the right to health under Article 12 of the ICESCR broadly and inclusively, asserting that:

[The right] is not confined to the right to health care. On the contrary, the drafting history and the express wording of article 12.2 acknowledge that the right to health embraces a wide range of socio-economic factors that promote conditions in which people can lead a healthy life, and extends to the underlying determinants of health .... ${ }^{106}$

The right to health therefore encompasses a wide array of underlying factors that impact health, far beyond medical treatment and services. These underlying determinants of health include, at a minimum, access to safe and potable water; adequate sanitation; adequate supply of safe food, nutrition, and housing; healthy occupational and environmental conditions; access to health-related education and information (including on sexual and reproductive health); and participation in health-related decision making at community, national, and international levels. ${ }^{107}$

General Comment 14 recognizes that the right to health creates both freedoms and entitlements. ${ }^{108}$ In providing an "opportunity for people to enjoy the highest attainable level of health" ${ }^{\text {"109 }}$ a state must consider the four interrelated elements of availability, accessibility, acceptability, and quality when assessing its compliance with its obligations:

- Availability - the state must ensure that resources integral to health, including sanitation, safe and potable drinking water, functional health services, trained health care

\footnotetext{
${ }^{105}$ ICESCR, supra note 5, art. 21 ("The Economic and Social Council may submit from time to time to the General Assembly reports with recommendations of a general nature ...."). In 1985, the Economic and Social Council established the Committee on Economic, Social and Cultural Rights (CESCR) to carry out the monitoring functions under Part IV of the ICESCR. ECOSOC Res. 1985/17 (May 28, 1985), available at http://ap.ohchr.org/documents/E/ECOSOC /resolutions/E-RES-1985-17.doc.

106 General Comment 14, supra note 10, II 4 (emphasis added).

107 Id. $\$ 11$.

${ }^{108}$ Id. 118.

${ }^{109}$ Id. \ 12.
} 
professionals, adequate treatment facilities, and access to essential medicines exist in "sufficient quantities."

- Accessibility - the state must eliminate barriers to access to health facilities, goods, and services, whether these barriers are imposed through economic, geographic, physical, or informational means.

- Acceptability - the state's health facilities, goods, and services must be adequate, according to cultural traditions and standards of medical ethics.

- Quality - the state's health facilities, goods, and services must adhere to levels of quality consistent with medical and scientific standards. ${ }^{10}$

Further, states assume three types of obligations in their efforts to realize the substance of these commitments under the right to health:

- The duty to respect demands that states avoid interference with the right to health through its actions or omissions. ${ }^{111}$

- The duty to protect imposes a requirement on states to engage in efforts to constrain the actions of third parties that may undermine the right to health. ${ }^{112}$

- The duty to fulfill mandates that states take affirmative steps, within the limitations of the state's available resources, to achieve the right to health. ${ }^{113}$

General Comment 14 recognizes the interplay between governmental and non-governmental actors in creating a resilient public health system that can adequately support the necessary range of underlying determinants of health. Further, states must adopt a national strategy to realize the right to health, promulgate the necessary legal infrastructure to support these measures, and develop an implementation plan with appropriate transparency and accountability. ${ }^{14}$

\footnotetext{
${ }^{110} \mathrm{Id}$.

111 Id. 934.

${ }^{112}$ Id. $\$ 35$.

${ }^{113} / d .936$.

${ }^{114}$ Id. 94 53-56.
} 


\section{Reproductive Health Rights Under the Right to Health Model}

The right to health model employs a different approach than the reproductive rights model to characterize reproductive health rights. Given its basis on the right to health, as developed through multiple international instruments and interpretative documents, this model seeks to uphold the foundational aspects of human rights and related conditions integral to reproductive health. These foundational human rights aspects of reproductive health include efforts to provide for the conditions and determinants necessary to allow for good reproductive health to flourish. ${ }^{115}$

The essence of this approach is captured effectively by applying three foundational concepts embedded in General Comment 14 to reproductive health. First, since the right to health depends upon "a wide range of socio-economic factors that promote conditions in which people can lead a healthy life," $" 116$ the realization of reproductive health rights demands state action that identifies and supports these factors and conditions. Thus, reproductive health rights should encompass efforts to refrain from "limiting access to contraceptives and other means of maintaining sexual and reproductive health," ${ }^{117}$ to prevent and treat diseases affecting women that may impact reproductive functioning, to provide access to a full range of high quality and affordable reproductive health services, to reduce women's health risks by lowering rates of maternal mortality and protecting women from domestic violence, to remove "all barriers interfering with access" to reproductive health services, education and information, and "to undertake preventive, promotive and remedial action to shield women from the impact of harmful traditional cultural practices and norms that deny them their full reproductive rights." 118

The second integral concept for understanding reproductive health rights under the right to health model involves recognizing that the underlying determinants of health play a vital role in achieving good health outcomes. Underlying determinants, such as "food and

115 The idea that social and economic determinants of health play an important role in public health outcomes has gained significant support from public health and human rights scholars. See, e.g., Michael Marmot, Social Determinant of Health Inequalities, 365 LANCET 1099 (2005); Michael G. Marmot \& Ruth Bell, Action on Health Disparities in the United States: Commission on Social Determinants of Health, 301 JAMA 1169 (2009). In addition, a number of scholars have developed theories of health capabilities designed explicitly to allocate resources in ways designed to enhance an individual's ability to function. See generally JENNIFER PRAH RUGER, HEALTH AND SOCIAL JUSTICE (2009).

${ }^{116}$ General Comment 14, supra note 10, II 4.

${ }^{117}$ Id. $\$ 34$.

118 Id. $\mathbb{1} 21$. 
nutrition, housing, access to safe and potable water and adequate sanitation, safe and healthy working conditions, and a healthy environment" $" 119$ can have an important effect on reproductive health. In settings where these determinants are not safeguarded, their absence can destabilize political, social, and economic conditions and undermine reproductive health rights.

Third, reproductive health rights under this model acknowledge that other human rights in addition to the right to health comprise "integral components" of the right to health. ${ }^{120}$ This observation, included by the CESCR in General Comment 14, incorporates the Vienna Declaration's recognition of the interconnectedness of human rights, ${ }^{121}$ a concept that has been described by Professor Rosalind Petchesky as the "indivisibility principle." 22 Human rights and their effects are sufficiently integrated with each other that the realization of foundational rights such as access to education, availability of health services, and protection from violence all contribute to the ability of a woman to exercise her decisional rights related to reproductive choice. ${ }^{123}$ Thus, just as reproductive health and human rights are inextricably linked, ${ }^{124}$ the attainment of reproductive health rights demands the realization of other supportive human rights.

Notably, these factors, conditions, underlying determinants, and integral components are drawn from both civil and political rights and economic, social, and cultural rights. Indeed, it is possible to interpret the foundational aspects of human rights very broadly under this model to even include decisional rights as foundational to achieve

${ }^{119}$ Id. $\$ 4$.

${ }^{120}$ See id. If 3 "The right to health is closely related to and dependent upon the realization of other human rights, as contained in the International Bill of Rights, including the rights to food, housing, work, education, human dignity, life, non-discrimination, equality, the prohibition against torture, privacy, access to information, and the freedoms of association, assembly and movement. These and other rights and freedoms address integral components of the right to health.").

${ }^{121}$ See Vienna Declaration, supra note 45, 115.

122 Rosalind P. Petchesky, Human Rights, Reproductive Health and Economic Justice: Why They Are Indivisible, REPROD. HEALTH MATTERS May 2000, at 12, 12-13.

123 Id. at 13.

${ }^{124}$ Seminal work in the field of health and human rights has recognized that health and human rights have three compelling interrelationships First, reproductive health advances human rights. Women and men who have the ability to reproduce with the methods and timing of their own choosing are likely to be able to participate in other social, political, and economic activities. Second, the protection and recognition of other human rights supports reproductive health. This relationship can be demonstrated across a wide range of rights. Third, protection of the right to health generally can bolster healthy reproductive choices and access to necessary services. Political rights and protections from abuse and violence ensure that women have the ability to make decisions about their reproductive activities. See Jonathan Mann et al., Health and Human Rights, 1 HEALTH \& HUM. RTS. 6, 12-22 (1994) (outlining three relationships between health and human rights). 
good reproductive health. So, for example, the liberty and privacy rights that support a woman's right to make reproductive decisions buttress the foundations of reproductive health, as protection of these rights can support timely interventions to protect a woman's reproductive health in the form of accessing available contraceptive or reproductive health services. ${ }^{125}$ In settings where decisional rights are undermined or constrained, women's reproductive health may suffer.

The characterization of reproductive health rights under the right to health model is susceptible to several criticisms. One concern may be that this approach presents a concept of reproductive health rights that is too broad. If reproductive health rights encompass all of the enabling conditions and underlying determinants applicable to realizing the right to health as well as the related human rights interconnected with this goal, the right to reproductive health is very broad indeed. ${ }^{126}$ Nevertheless, a broad model such as this does not require all of these aspects to be satisfied at once. Rather, it implores governments to take all of these factors into account when addressing reproductive health so as to understand the complexity and interrelated effects that the conditions have on realizing the right to reproductive health. An additional criticism of this approach revolves around potential impediments to enforceability. Basing this model on the right to health raises enforceability problems in countries that have not ratified the ICESCR, such as the United States, and limits enforceability in countries that recognize this right due to the constraint of progressive realization. ${ }^{127} \mathrm{~A}$ final critique is the concern that placing a higher priority on reproductive health may come at the expense of decisional rights and thereby undermine autonomy or bodily integrity. ${ }^{128}$ There is little indication, however, that the decisional and foundational human rights aspects of reproductive health are inherently incompatible. Indeed, the discussion above suggests that these categories may instead be mutually reinforcing, provided that the decisional aspects of human rights continue to

${ }^{125}$ See sources cited supra note 49.

${ }^{126}$ See Gostin, supra note 96 , at 271 (raising a similar criticism of the broad definition of health contained in the WHO Constitution).

${ }^{127}$ See Alston, supra note 80, at 128-132 (commenting on the justiciability of economic and social rights in the United States); Michael J. Dennis \& David P. Stewart, Justiciability of Economic, Social, and Cultural Rights: Should There Be an International Complaints Mechanism to Adjudicate the Rights to Food, Water, Housing, and Health?, 98 AM. J. INT'L LAW, 462, 463-65, 471-73 (2004) (explaining the difficulties of enforcing economic, social, and cultural rights such as the right to health and describing the debate over applying a standard of progressive realization to its application).

${ }^{128}$ See, e.g., Siegel, Reasoning from the Body, supra note 9. 
receive sufficient protection. Moreover, the model articulated in General Comment 14 clearly illustrates the importance of decisional factors in the right to health. ${ }^{129}$

\section{CONCEIVING Reproductive Health as a Human Right}

The purpose of defining reproductive health as a human right is to acknowledge the fundamental importance of reproductive health in our society and to imbue reproductive health with the legal and ethical protections afforded human rights. ${ }^{130}$ Several factors support the idea of considering reproductive health as a human right: its centrality to human functioning; its contribution to overall human health; its interconnectedness with numerous other human rights; and its relationship with social factors involving sexuality, gender, and power.

The models outlined above demonstrate that the content and focus of reproductive health rights can differ depending on the perspectives and priorities advanced by governments, advocates, scholars, and individuals, as well as the jurisprudential development of rights within court systems. The scope and justiciability ascribed to reproductive health rights affect the ability of individuals to claim these rights. Likewise, the reach of reproductive health rights impacts the difficulty of respecting, protecting, and fulfilling these rights.

\section{A. Bridging the Discourses: A Combined Model for Reproductive Health Rights}

In charting a course for the future of reproductive health rights, the balance should swing toward supporting the foundational aspects of reproductive health rights, while maintaining strong support for the decisional aspects of reproductive health rights. This health-centered approach can more widely incorporate an extensive range of integral components, underlying determinants, and enabling conditions to attain good reproductive health using the human rights paradigm. In addition, this approach supports the recognition of a broad and nuanced understanding of the right to reproductive health, which potentially could bolster significantly both reproductive health outcomes and the rights of women to make unimpeded reproductive health decisions.

${ }^{129}$ General Comment 14, supra note 10, I 8 (emphasizing the right to control one's health and to be free from interference that would prevent the achievement of positive health outcomes).

${ }^{130} \mathrm{Cf}$. HENKIN, supra note 44 , at 21-22 (discussing the development of international remedies for violations of the ICCPR and ICESRC). 
The contrasting reproductive rights and right to health models presented in the preceding sections described two competing notions of reproductive health rights. The reproductive rights model links reproductive health rights closely with decisional aspects of human rights, coupled with an implicit understanding of the importance of other rights and conditions in supporting reproductive decisions and their consequences. In effect, while this model recognizes the diversity in factors contributing to reproductive health, the rights claims being advanced focus squarely on decisional autonomy.

By comparison, the right to health model also acknowledges the broad panoply of rights and conditions that underlie good reproductive health, but instead places the emphasis on health and the foundational aspect of human rights that support health, including its core components and underlying determinants. This distinction is consequential because the right to health model shifts the discourse around reproductive health rights toward health and more explicitly denotes the intricate interrelationship between human rights and the foundational conditions needed to ensure their attainment. ${ }^{131}$

Combining the two models provides one way to pursue this goal. Considering the two models together, it is possible to establish a conception of reproductive health rights that appropriates the most salient aspects of both models to strengthen and broaden how reproductive health rights are defined within legal, political, and social discourses. Reproductive health rights, as defined under this combined model, would represent human rights that support reproductive health and well-being, including both the foundational and decisional aspects of those human rights. ${ }^{132}$ This definition would encompass, at a minimum, rights that protect the ability of an individual to decide whether and when to reproduce; assurances of reasonable access to adequate reproductive health services and contraceptive services; alleviation of social conditions that may

131 This shift in discourse from negative to positive rights has been urged by legal scholars. See generally Dempsey \& Meier, supra note 9, at 83 (arguing that a positive reproductive rights discourse would complement the current negative rights framework). However, the comparison being made here relies less on the negative vs. positive rights distinction and more on the dichotomy between decisional and foundational aspect of human rights in the context of reproductive health.

132 While the categorization differs somewhat, other scholars have differentiated categories of reproductive rights that did not strictly use the positive/negative rights distinction. See Rebecca J. Cook \& Bernard M. Dickens, From Reproductive Choice to Reproductive Justice, 106 INT'L J. GYNECOLOGY \& OBSTETRICS 106, 106 (2009) (describing categories of reproductive health rights as rights to reproductive choice and rights to reproductive justice, respectively). 
undermine reproductive health; and fortification of health and social systems that support good reproductive health. ${ }^{133}$

Weaving together the notions of reproductive health rights extant within the two models allows for a more expansive, and frankly, a more complex understanding of reproductive health rights that considers both decisional and foundational aspects of human rights as integral to achieving good reproductive heath. These areas coalesce to form a shared set of reproductive health rights, albeit one that-given its strong health orientation-aligns more closely with the right to health model. In addition, reproductive health rights under the combined model draw from across the human rights spectrum and incorporate a range of human rights norms to attain the dual goals of protecting reproductive agency and reproductive health.

\section{B. Expanding the Global Salience and Enforceability of Reproductive Health Rights}

Efforts to expand the salience and legal enforceability of reproductive health rights are integral factors in improving global reproductive health outcomes. The conceptual framework for reproductive health rights developed above provides a useful model to follow. But this approach will only be effective if accompanied by contemporaneous efforts to bolster the recognition of reproductive health as a human right in legal and policy discourses, to further develop substantive norms related to reproductive health rights, to augment the justiciability of rights claims for violations of reproductive health rights, and to strengthen and diversify the human rights and public health infrastructures available to support reproductive health rights. In order to advance reproductive health rights in each of these four areas, longstanding traditions and persistent limitations may need to be confronted and overcome.

\section{Recognition of Reproductive Health Rights in Law and Policy Decisions}

The approach applied to frame reproductive health rights under the combined model builds upon developments within the community of reproductive health advocates and international policy-makers. The adoption of the human rights paradigm at the 1994 International Conference on Population and Development (ICPD) in Cairo, Egypt, marked a substantial redefinition of reproductive health within

${ }^{133}$ Many of these factors are indeed referenced in the International Conference on Population and Development, Programme of Action. See infra Part III.B.1. 
international policy on health and development. Prior to the ICPD the focus of much of the international debate on issues of reproductive health centered on population control, grounded in a neo-Malthusian mindset fixed on concern about overpopulation and population-driven poverty. ${ }^{134}$

The ICPD meeting was convened to chart a way forward to drastically improve reproductive rights outcomes with a twenty-year plan. Building on the foundation and momentum generated by the Vienna Declaration, ${ }^{135}$ which had been issued the prior year, participants in the ICPD sought to directly link reproductive health to human rights. ${ }^{136}$

The ICPD declaration and the ensuing Programme of Action ${ }^{137}$ redefined reproductive health as a broad public health concern grounded in political, social, and economic realities and conjoined with human rights. ${ }^{138}$ The ICPD received widespread praise for representing a paradigm shift in the modern global conception of reproductive health, moving away from the prior focus on fertility and population control, and toward an approach that prioritized rights-based approaches to protecting reproductive health. ${ }^{139}$

The ICPD Programme of Action provided a clear articulation of reproductive health as a human right and remains the most compelling international statement of a right-based conception of reproductive health. ${ }^{140}$ Paragraph 7.2 states:

Reproductive health is a state of complete physical, mental and social well-being and not merely the absence of disease or infirmity, in all matters relating to the reproductive system and to its functions and processes. Reproductive health

${ }^{134}$ See Laura Reichenbach, The Global Reproductive Health and Rights Agenda: Opportunities and Challenges for the Future, in REPRODUCTIVE HEALTH AND HUMAN RIGHTS, supra note 4 , at $21,24-26$ (discussing the international policy regarding reproductive health prior to the ICPD).

135 Vienna Declaration, supra note 45, at II 5.

136 Reichenbach, supra note 134 , at 26-27.

${ }^{137}$ ICPD Programme of Action, supra note 7.

${ }^{138}$ See id. TI 7.2, 7.3 (defining reproductive health as including both access to reproductive health services and the ability to make reproductive decisions); see also COOK ET AL., supra note 1 , at 12 (noting the broad conception of reproductive health adopted by the ICPD Programme of Action).

${ }^{139}$ See, e.g., Reichenbach, supra note 134, at 27 ("ICPD resulted in a paradigm shift in thinking about how to improve women's lives by proposing a rights-based approach to the provision of reproductive health services, to achieve broader development goals of gender equality, equity, and women's empowerment.'); Rhonda Copelon \& Rosalind Petchesky, Toward an Interdependent Approach to Reproductive and Sexual Rights as Human Rights: Reflections on the ICPD and Beyond, in FROM BASIC NEEDS TO BASIC RIGHTS: WOMEN'S Claims to HuMaN Rights 343 (Margaret Schuler ed., 1995).

140 ICPD Programme of Action, supra note 7, at II 7.2. 
therefore implies that people are able to have a satisfying and safe sex life and that they have the capability to reproduce and the freedom to decide if, when and how often to do so. Implicit in this last condition are the right of men and women to be informed and to have access to safe, effective, affordable and acceptable methods of family planning of their choice, as well as other methods of their choice for regulation of fertility which are not against the law, and the right of access to appropriate health-care services that will enable women to go safely through pregnancy and childbirth and provide couples with the best chance of having a healthy infant. $^{141}$

The legacy of the ICPD goes beyond its explicit recognition of the link between reproductive health and human rights. While the goals of the ICPD remain elusive in many parts of the world, ${ }^{142}$ the rights-based approaches introduced in the Programme of Action have revolutionized global health practice and inspired the application of rights-based strategies in subsequent international policy agreements and initiatives. The ICPD approach was followed at the Fourth World Conference on Women in Beijing in 1995, which similarly recognized rights-based strategies for protecting reproductive freedoms and equality for women. ${ }^{143}$ Several experts have claimed that the ICPD strongly influenced the later development of the Millennium Development Goals. ${ }^{144}$ Others are less sanguine about the continued importance of reproductive health in the global health agenda. ${ }^{145}$

In some ways the Vienna Declaration and the ICPD acted as a predecessor and influential model for General Comment 14 to the ICESCR. The explicit recognition of the interconnectedness of all human rights informs the broad conception of the right to health described in the General Comment. Moreover, the inclusion of both

${ }^{141} \mathrm{ld}$.

${ }^{142}$ See Mindy Jane Roseman \& Laura Reichenbach, Intemational Conference on Population and Development at 15 Years: Achieving Sexual and Reproductive Health and Rights for All?, 100 AM. J. PUB. HEALTH 403 (2010) (assessing the achievements of the ICPD fifteen years later).

${ }^{143}$ See Fourth World Conference on Women, Beijing, P.R.C., Sept. 4-15, 1995, Platform for Action, I 1, U.N. Doc. A/CONF.177/20, Annex II (Oct. 17. 1995) ("Equality between women and men is a matter of human rights ....").

${ }^{144}$ See, e.g., Adrienne Germain \& Jennifer Kidwell, The Unfinished Agenda for Reproductive Health: Priorities for the Next 10 Years, 31 INT'L FAM. PLAN. PERSP. 90, 90 (2005) ("[T]he Cairo meeting provided a foundation for the MDGs.").

${ }^{145}$ See, e.g., Reichenbach, supra note 134 , at $27-28$ (noting that reproductive health was "glaringly" excluded as a Millennium Development Goal). 
freedoms and entitlements within the right to health essentially brings together civil and political rights and economic, social, and cultural rights, an approach that corresponds to the ICPD understanding of human rights.

The combined model's articulation of reproductive health rights, which draws heavily from General Comment 14 , can provide a basis for reinvigorating the linkage between reproductive health and reproductive rights in public discourse. Keeping these issues prominently on the global health agenda has presented a challenge in the years since the Cairo and Beijing conferences. ${ }^{146}$ Applying reproductive health rights to international development and public health efforts remains a vital concern for women's health around the world. Both the twenty-year ICPD strategy and the Millennium Development Goals have target dates of $2015 .{ }^{147}$ The impending reviews of these initiatives present a strong opportunity to revisit these ideas, foster greater respect for reproductive health rights, and provide a renewed impetus to enhance reproductive health outcomes. ${ }^{148}$

\section{Developing the Normative Content of Reproductive Health Rights}

The development of reproductive health rights norms-the substantive content, scope, and applicability of reproductive health rights-has proceeded vigorously in recent years. ${ }^{149}$ A multiplicity of human rights instruments, explanatory documents, policy statements, judicial decisions, scholarly analyses, and other sources have contributed to the normative development of reproductive health rights. At the international level, key sources providing a normative context for reproductive health rights include CEDAW, the ICPD

\footnotetext{
146 See id.

${ }^{147}$ ICPD Programme of Action, supra note 7, II 1.14.; MDGs REPORT 2010, supra note 15, at 4-5.

${ }^{148}$ Efforts to enhance reproductive health rights have been mirrored by efforts to strengthen public health systems. Recognizing that health systems form the backbone of creating conditions to achieve the right to health, the Special Rapporteur on the Right to Health has advocated for taking systemic approaches to improve the health infrastructure, and by extension, some of the primary underlying determinants of health. See Paul Hunt \& Gunilla Backman, Health Systems and the Right to the Highest Attainable Standard of Health, 10 HEALTH \& HUM. RTS. 81 (2008); see also Gunilla Backman et al., Health Systems and the Right to Health: An Assessment of 194 Countries, 372 LANCET 2047 (2008) (studying various countries' health systems and arguing that the right to health is required under human rights law); Lynn P. Freedman, Drilling Down: Strengthening Local Health Systems to Address Global Health Crises, in REALIZING THE RIGHT TO HEALTH 407, 416-18 (Andrew Clapham \& Mary Robinson eds., 2009) (advocating for a rights-based approach to strengthening local health systems).

${ }^{149}$ See, e.g., Gable, supra note 11 , at 535 (examining the normative development of the human right to health).
} 
Programme of Action, General Comment 14 to the ICESCR, and Reports of the United Nations Special Rapportuer on the Right to Health. National legislation and policy on reproductive health may adopt international standards, which often are tailored to comport with national capabilities and political realities. NGO reports and thoughtful scholarly writings linking reproductive health and human rights may address international or national concerns. ${ }^{150}$

Norm development is necessary because international human right instruments do not provide much detail about the scope of human rights protections contained therein. The promulgation of General Comment 14 and the activities of the Special Rapportuer on the Right to Health provide good examples of this norm-making process, taking the vague language of Article 12 of the ICESCR and producing detailed explanations of what rights protections are actually required under the right to health. General Comment 14, for example, explains that "the right to control one's health and body" arises from the right to health, as well as from the right to freedom from discrimination and harmful cultural practices linked with reproductive health risks. ${ }^{151}$ The Special Rapporteur on the Right to Health has found that in the context of reproductive health, rape and other forms of sexual violence, forced pregnancy, non-consensual contraception (forced sterilization or abortion), female genital mutilation, forced marriages, and child marriages are "fundamentally and inherently inconsistent with the right to health." 152

Entitlements created by the right to health include a right to an adequate system of health protection. The conception of the right to health advanced by General Comment 14 further elaborates that this "may be understood as requiring measures to improve child and maternal health, sexual and reproductive health services, including access to family planning, pre- and post-natal care, emergency obstetric services and access to information, as well as to resources necessary to act on that information." 153 The Special Rapporteur added that "access to such vital health services as voluntary testing, counselling and treatment for sexually transmitted infections,

${ }^{150}$ See, e.g., COOK ET AL., supra note 1, at 149-215 (providing a detailed normative comparison of human rights that apply to reproductive health).

${ }^{151}$ General Comment 14, supra note 10, TI 8, 18, 21.

152 U.N. Econ. \& Soc. Council [ECOSOC], Comm'n on Human Rights, Report of the Special Rapporteur: The Right of Everyone to the Enjoyment of the Highest Attainable Standard of Physical and Mental Health, I 25, U.N. Doc. E/CN.4/2004/49 (Feb. 16, 2004) (prepared by Paul Hunt) [hereinafter Special Rapporteur Report]. The Special Rappoteur also concluded that "human rights law places obligations on duty-bearers to do all they can to dismantle the barriers to sexual and reproductive health." Id. $\mathbb{1} 15$.

${ }^{153}$ General Comment 14, supra note 10, II 14. 
including HIV/AIDS, and breast and reproductive system cancers, as well as infertility treatment" were required. ${ }^{154}$

The substantial normative development of the right to health has important implications for reproductive health rights. As these examples illustrate, international institutional actors (in this case the CESCR and the Special Rapporteur) have begun to develop fairly specific requirements for protecting and fulfilling reproductive health rights. Further development in other topical areas should be pursued, ${ }^{155}$ particularly related to the normative content of the underlying determinants of reproductive health and the connection between other human rights and reproductive health rights. ${ }^{156}$ Articulating detailed norms within the context of a right to reproductive health more strongly establishes the connection between human rights and reproductive health and provides added legitimacy for rights-based approaches and rights claims in this field. It puts states on notice that they must accommodate a wide range of rights and determinants to satisfy their human rights obligations. These norms can encourage the establishment of more robust and innovative rights-based approaches to reproductive health, which can then be tested and shared.

Additionally, framing issues of reproductive health in human rights terms creates a legally enforceable claim on states that have recognized the right to health. Legal recognition of these claims under the right to health may expand the possibilities for justiciable recourse for violations of reproductive health rights. Thus, rights claims for reproductive health rights can be made stronger as a result of the normative development of the right to health.

While adopting an approach to reproductive health rights that embraces the underlying determinants model provides substantial additional context to this right, it also complicates the obligations of the state to meet these determinants. Many of the underlying determinants of health, including universal education, social

154 Special Rapporteur Report, supra note 152, II 29.

155 Underlying determinants would involve, among other things, safe and healthy living and working conditions, access to food, nutrition, medicines and medical care, adequate housing and social services to support reproduction and reproductive decisions, and a strong health system. A number of commentators have recognized the importance of such underlying social determinants to reproductive health. See, e.g., COOK ET AL., supra note 1, at 149-215; Helen de Pinho, On the "Rights" Track: The Importance of a Rights-Based Approach to Reducing Maternal Deaths, in REALIZING THE RIGHT TO HEALTH, supra note 148, at 111; Barbara Wilson, Social Determinants of Health from a Rights-Based Approach, in REALIZING THE RIGHT TO HEALTH, supra note 148, at 60.

156 Special Rapporteur Report, supra note 152, III 34, 40 (noting that the rights to education, accessible information, privacy protections, protection from violence, among others are all components of realizing the right to reproductive health). 
and gender equality, and non-discrimination, may require the development of substantial efforts in other sectors of society and consequently, will be difficult to secure.

\section{Legal Recognition and Justiciability of Reproductive Health Rights}

Solidifying the legal enforceability of a human right to reproductive health will be difficult for a number of reasons. While the vast majority of countries in the world have ratified the ICESCR and other international human rights treaties that include the right to health, several holdouts exist, most notably the United States. ${ }^{157}$ The United States has been extremely reluctant to ratify any international human rights treaty that would place affirmative obligations on the government to guarantee services. ${ }^{158}$ This opposition to positive rights is unlikely to change in the short term. Therefore, in the United States, some aspects of reproductive health rights will be difficult to enforce under current law. Nevertheless, certain decisional aspects of reproductive health rights clearly receive protection under United States constitutional law, such as rights to privacy, to access contraception, ${ }^{159}$ and for a woman to terminate a pregnancy. ${ }^{160} \mathrm{~A}$ number of other countries have banned FGM, prohibiting anyone from performing the procedure. ${ }^{161}$

In countries that do recognize the right to health and other economic, social, and cultural rights, the chances for reproductive health rights claims being enforced is higher, but certainly not guaranteed. Even countries that have ratified the ICESCR and other international human rights treaties that recognize the right to health remain deficient in their ability to respect, protect, and fulfill these human rights obligations. ${ }^{162}$ Moreover, some aspects of the right to

${ }^{157}$ Alston, supra note 80 , at $120,121-23$.

158 Id. at 133-34.

${ }^{159}$ Griswold v. Connecticut, 381 U.S. 479 (1965).

${ }^{160}$ Roe v. Wade, 410 U.S. 113 (1973).

${ }^{161}$ Special Rapporteur Report, supra note 152, II 44 (noting several countries that have legally banned FGM: Burkina Faso, Ghana, Senegal, and the United Kingdom).

${ }^{162}$ The Special Rapporteur on the Right to Health has documented numerous violations in a series of country reports. See, e.g., The Special Rapporteur on the Right to Health, Report of the Special Rapporteur on the Right of Everyone to the Enjoyment of the Highest Attainable Standard of Physical and Mental Health: Addendum, Summary of Cases Transmitted to Governments and Replies Received, delivered to the Human Rights Council and the General Assembly, U.N. Doc. A/HRC/4/28/Add.1 (Feb. 23, 2007) (describing communications with various national governments regarding allegations of right-to-health violations in their countries); The Special Rapporteur on the Right to Health, Report of the Special Rapporteur on the Right of Everyone to the Enjoyment of the Highest Attainable Standard of Physical and Mental Health: Addendum, Summary of Communications Sent to and Replies Received from Governments and Other Actors, delivered to the Human Rights Council and the General Assembly, U.N. Doc. A/HRC/7/11/Add.1 (Mar. 4, 2008) (same); The Special Rapporteur on the 
health are subject to progressive realization. ${ }^{163}$ Progressive realization limits a country's obligation to provide services required under the right to health so long as it is making reasonable progress toward fulfilling the right given its resource constraints. ${ }^{164}$

Right to health claims have gained prominence in litigation strategies in countries such as Venezuela, ${ }^{165}$ Ecuador, ${ }^{166}$ and South Africa, ${ }^{167}$ under national constitutional protections for the right to health. Many of these cases involved claims for access to HIV medications, a common violation that has significant implications for reproductive health. However, right to health cases remain rare. ${ }^{168}$

Where legally recognized, the full panoply of reproductive health rights should be deployed to protect reproductive health and reproductive autonomy. Legislative and judicial strategies employing reproductive health rights will be more salient in some countries, while reproductive autonomy rights will be more salient in others. Simultaneously, advocates for reproductive health rights could urge governments to adopt greater legal recognition of reproductive health rights, including though the ratification of relevant human rights treaties or the establishment of human rights protections under domestic law. Nevertheless, these constraints on enforceability present a substantial hurdle for the widespread acceptance and implementation of reproductive health rights.

Right to Health, Report of the Special Rapporteur on the Right of Everyone to the Enjoyment of the Highest Attainable Standard of Physical and Mental Health: Addendum, Summary of Communications Sent to and Replies Received from Governments and Other Actors, delivered to the Human Rights Council and the General Assembly, U.N. Doc. A/HRC/1 1/12/Add.1 (May 18,2009 ) (same).

${ }^{163}$ See Special Rapporteur Report, II 27 (explaining that an individual's right to control his or her body is not subject to progressive realization or contingent on resource constraints).

164 See General Comment 14, supra note 10, I 47.

${ }^{165}$ Cruz del Valle Bermudez v Ministerio de Sanidad y Asistencia Social [Ministry of Health and Social Welfare], Tribunal Supremo de Justicia de Venezuela [Supreme Court of Justice of Venezuela], Expediente No. 15-789, Sentencia No. 196 (finding that the failure of the state to provide anti-retroviral drugs to HIV infected person violated the right to health).

${ }^{166}$ Mendoza \& Ors v. Ministry of Public Health, Tribunal Constitucional, Resolucion No. 0749-2003-RA (Jan. 28, 2004) (Ecuador) (finding that the failure of the state to provide HIV treatment violated the right to health).

${ }^{167}$ Minister of Health v. Treatment Action Campaign (TAC), 2002 (10) BCLR 1033 (CC) (S. Afr.) (finding that the failure of the state to provide anti-retroviral drugs to prevent mother-to-child HIV transmission was a violation of the right to health under the South African Constitution).

${ }^{168}$ Iain Byme, Enforcing the Right to Health: Innovative Lessons from Domestic Courts, in REALIZING THE RIGHT TO HEALTH, supra note 148, at 525-27 (analyzing domestic court decisions applying the right to health in a variety of jurisdictions). 


\section{Developing Systemic Redundancy to Uphold Reproductive Health Rights}

Given the multiple human rights systems and legal systems that offer rights protection, in some jurisdictions multiple mechanisms will exist through which to assert reproductive health rights. For example, a woman who faces insufficient access to HIV medications in Ecuador may assert her right to health through a domestic legal action (amparo) ${ }^{169}$ or through bringing a complaint before the Inter-American Commission on Human Rights. ${ }^{170}$ This duplicative infrastructure presents an individual with options on where to bring a rights claim. As human rights systems have proliferated, the opportunity to have multiple layers of human rights protection has increasingly become possible. ${ }^{171}$ This redundancy can benefit individuals by giving them multiple avenues through which to pursue their rights claims.

Similar redundancy has developed with regard to normative aspects of human rights. Developing the normative content of reproductive health rights has become a multifaceted endeavor. With multiple jurisdictions considering the content of human rights provisions, courts and international institutions have often found other institutions developing norms for the same categories of rights. In several instances, institutions have shared their insights, and have even referred to or incorporated these norms into their own legal interpretations. ${ }^{172}$

The availability of structural and normative redundancy in the human rights system could accelerate the normative development of reproductive health rights or the resolution of individual rights claims. Alternatively, it could complicate these processes. More research is needed to assess the implications of this situation.

${ }^{169}$ Mendoza \& Ors v. Ministry of Public Health, Tribunal Constitucional, Resolucion No. 0749-2003-RA (Jan. 28, 2004) (Ecuador).

${ }^{170}$ American Convention on Human Rights, art. 48, opened for signature Nov. 22, 1969 , 1144 U.N.T.S. 123, 136 (entered into force July 18, 1978) (outlining procedures for petitioning the American Commission on Human Rights).

171 See Gable, supra note 11, at 535 (examining the global proliferation of human rights systems)

${ }^{172} C f$. Lance Gable et al., Mental Health and Due Process in the Americas: Protecting the Human Rights of Person Involuntarily Admitted to and Detained in Psychiatric Institutions, 18 PAN AM. J. PUBLIC HEALTH 366, 367 (2005) (arguing for more stringent enforcement of human rights standards for mentally disabled individuals in the Americas, and observing that the Inter-American Human Rights System is "poised to take the same journey as the European [Human Rights] System," which has had significant success in protecting the rights and interests of the mentally disabled). 


\section{CONCLUSION}

International and national initiatives, including developments in human rights law, ICPD, and the MDGs, have spurred advances in reproductive health in recent years. Considerable progress has been made in highlighting the close link between human rights and reproductive health, and some countries have recognized the value of using rights-based approaches to foster improvements in reproductive health. Yet, by many measures, reproductive rights and reproductive health remain insufficiently realized around the world. Women continue to face significant obstacles to accessing necessary reproductive health services and related resources. Women often encounter laws, policies, and social and cultural norms that enforce subjective morality, exert control over reproductive behaviors and decisions, limit autonomy and privacy, and perpetuate stigma and discrimination against women due to their reproductive choices.

Advancements in reproductive rights and the right to health have in many ways traveled on parallel tracks, often adhering to the artificial dividing lines between negative and positive rights established in international human rights law or the decisional and foundational aspects of these rights. This bifurcated discourse has led to the erection of walls between those seeking reproductive rights and those advocating better reproductive health within a right to health framework. There remains ample opportunity to continue to deconstruct this division and create a more integrated conception of reproductive health rights. 